Климова Я.А

\title{
ПРОБЛЕМЫ РАСШИРЕНИЯ ПРОЦЕССУАЛЬНОЙ САМОСТОЯТЕЛЬНОСТИ ДОЗНАВАТЕЛЯ
}

\begin{abstract}
Аннотация: Предметом исследования является совокупность норм уголовно- процессуального кодекса Российской Федерации, регламентирующих правовой статус дознавателя, его компетенцию и полномочия. В частности, дается анализ проблемы расширения проиессуальной самостоятельности дознавателя в свете рассмотрения положений Проекта Федерального закона № $555400-6$ «О внесении изменений в Уголовно-прочессуальный кодекс Российской Федерачии в части наделения дознавателя правом обжалования некоторых решений прокурора по уголовному делу, поступивщему с обвинительным актом или обвинительным постановлением». Методологической основой исследования послужили общенаучные методы получения новых научных знаний, в частности, системноструктурный анализ, формальная логика и другие методы, позволяющие изучить во взаимосвязи правоотношения в сфере уголовного судопроизводства, а также частные методы - исторический, сравнительно-правовой. Научная новизна состоит в том, что в представленной работе с учетом последних изменений уголовно-процессуального законодательства России и внесенного законопроекта, находямегося на рассмотрении в Государственной Думе, исследованы проблемные аспекты нормативной регламентации процессуальной самостоятельности дознавателя. Делается вывод о необходимости комплексного организационного подхода к решению проблемы законодательного регламентирования прочессуальной самостоятельности дознавателя, с целью создания содной сторонь - оптимальных условий для скорейшего расследования преступлений и передачи дела в суд, с другой-сохранения установленных гарантий прав и законных интересов потерпевших, обвиняемых и других участников процесса.

Abstract: The subject of this research is the complex of the norms of the Criminal Procedure Code of the Russian Federation that regulate the legal status of an investigator, their competence and authority. The author also analyses the problems associated with expansion of the procedural autonomy of investigators in light of the reading of a Federal Bill No. 555400-6 "On amendments to the Criminal procedure code of the Russian Federation in the part of giving the investigator the right to appeal certain decisions of the Prosecutor in a criminal case, made by indictment or indictments decree". The scientific novelty consists in the fact that this work researches the problematic aspects of the normative regulation of the procedural autonomy of investigators, taking into account the recent changes to the Criminal Procedure Code of the Russian Federation and a bill that is currently being reviewed by the State Duma. The author makes a conclusion about the need of a complex organizational approach to the solution of the problem of legal regulation of the procedural autonomy of investigators, in order to create optimal conditions for a timely investigation of crimes and forwarding the case to the prosecutor on one hand, and ensuring protection of the rights and legal interests of victims, defendants, and other involved parties on the other.
\end{abstract}

Ключевые слова: Прочессуальная самостоятельность, дознаватель, законопроект, изменения, обжалование решений, прокурор, реформа, предварительное расследование, обвинительный акт, обвинительное постановление.

Keywords: Procedural autonomy, investigator, bill, changes, appeal of a decision, prosecutor, reform, preliminary investigation, indictment, indictment decree.

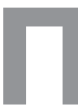

равительством Российской Федерации 26 июня 2014 г. на рассмотрение Государственной Думы Федерального Собрания Российской Федерации был внесен разработанный Министерством внутренних дел России Проект «О внесении изменений в Уголовнопроцессуальный кодекс Российской Федерации в части наделения дознавателя правом обжалования некоторых решений прокурора по уголовному делу, поступившему с обвинительным актом или обвинительным постановлением» [1]. Данный документ направлен, как указано в пояснительной записке, на укрепление правового статуса дознавателя путем регламентации его права отстаивать процессуальные решения по уголовному делу, принятые в ходе досудебного производства, и детализации процедуры обжалования.

Идея, положенная в основу законопроекта, не нова и имеет длинную историю. Так, о необходимости наделения дознавателя правом обжалования, а также возможности приостановления исполнения указаний прокурора дозна- вателем в случае их обжалования говорили И. Васильев, Д.Б. Гаврилов [2, с. 45; 3, с. 144].

Одним из аргументов за расширение процессуальной самостоятельности дознавателя является то, что на сегодняшний день отсутствуют существенные различия между правовой регламентацией предварительного следствия и дознания. Многие процессуалисты считают, что в УПК существует единая процессуальная форма. Так, по мнению Н.И. Скударевой, отличие между дознанием и предварительным следствием носит формальный характер [4, с. 3]. Об этом говорит и С. Гирько, полагающий, что грань различий дознания и предварительного следствия на сегодняшний момент оказалась стертой [5].

Действительно, при обнаружении признаков преступления эти органы обязаны возбудить уголовное дело в пределах их компетенции. И следователь, и дознаватель осуществляют производство по делу, принимают процессуальные решения об избрании меры пресечения, о предъявлении обвинения, по окончании расследования составляют итоговый процессуаль- 


\section{Право и политика $12(180) \cdot 2014$}

ный документ. В своей деятельности они руководствуются едиными требованиями уголовно-процессуального законодательства и уполномочены производить в принципе одинаковые следственные действия с целью выявления, фиксации, проверки и оценки доказательств. При этом следует обратить внимание на то, что решения, принимаемые в ходе дознания, имеют такую же юридическую силу, как и принимаемые при производстве предварительного следствия.

Представляет интерес и предложение А.М. Баранова, которое строится на том, что дознание, проводимое под руководством прокурора, должно стать основной формой досудебного производства по уголовным делам. Автор предлагает расширить сферу действия дознания, а по преступлениям небольшой и средней тяжести даже сделать его основной формой предварительного расследования [6, с. 25].

В пользу принятия законопроекта говорят данные официальной статистики, приведенные в пояснительной записке к законопроекту. Согласно этих данных в 2010 году прокурорами для производства дополнительного дознания, дознания в общем порядке, а также пересоставления обвинительного акта, производства дополнительного дознания и пересоставления обвинительного акта, возвращено 13814 уголовных дел, что составляет $3,7 \%$ от их общего количества, направленных в порядке статьи 226 УПК РФ, в 2011 году - 13194 (3,9\%), в 2012 году - 13836 (4,1\%), в 2013 году - 12818 (3,5\%). Анализ уголовных дел показал, что значительная их часть возвращена по основаниям, которые могли быть устранены в суде, а расследование закончено в кратчайшие сроки [7].

В этой связи представляется правильным стремление законодателя обеспечить процессуальную независимость органов предварительного расследования и логично наделить дознавателя правом на обжалование решения прокурора.

Однако, не следует полагать, что принятие указанного законопроекта позволить решить имеющуюся проблему, так как существуют весомые аргументы против введения процессуальной независимости дознавателя.

Так, несмотря на явное сходство со следствием, дознание - это все же усечённая и упрощенная форма расследования. В этом смысле производство по уголовному делу в форме дознания, предусматривающее специальные правила производства по уголовному делу, предполагает определенную скорость, быстроту рассмотрения материалов с целью реагирования на большое количество заявлений по преступлениями небольшой тяжести, очевидным, не представляющих сложность в расследовании, оптимизируя порядок доступа к правосудию в разумные сроки, чтобы как можно больше лиц, потерпевших от преступлений, могло в кратчайшие сроки получить доступ к правосудию. А полномочие по обжалованию решения прокурора может затягивать сроки расследования.

Следует обратить внимание, что некоторые процессуалисты предлагали, упразднив саму процедуру дознания, наделить орган дознания лишь правом возбуждения уголовных дел и производства неотложных следственных действий (Е. А. Нагаев, В. В. Нечаев, Ж. В. Эстерлейн). Другие исследователи считали необходимым исключить полномочия органа дознания по расследованию уголовных дел, с упразднением дознавателя в качестве субъекта уголовного судопроизводства, но при условии сохранения самого дознания, которое необходимо перепоручить для осуществления следователю, наряду с производством предварительного следствия (И. Г. Башинская) [8, с. 50].

Некоторые исследователи предлагают даже ликвидировать дознание. Например, А. Е. Лодкин считает целесообразным вместо двух форм производства предварительного расследования, оставить одну - предварительное следствие, что, по его мнению, позволит существенно снизить число нарушений при производстве расследования в форме дознания, оптимизировать досудебное производство в целом [9, с. 150].

Несмотря на то, что нормы ч. 4 ст. 41 и ч. 4 ст. 124 УПК РФ прямо закрепляют возможность дознавателя обжаловать решения прокурора, тем не менее такие решения являются для дознавателя обязательными для исполнения. А законопроект детально закрепляет право, процедуру и порядок обжалования конкретного решения прокурора, а именно решения о возвращении уголовного дела дознавателю для производства дополнительного дознания, пересоставления обвинительного акта или обвинительного постановления, о направлении уголовного дела дознавателю для производства дознания в общем порядке. Главное значение этих изменений заключается в том, что сейчас обжалование данных указаний не приостанавливает их исполнения, а проект закона предлагает закрепить в ч. 5 ст. 226 норму, согласно которой обжалование дознавателем решения прокурора о возвращении на дополнительное расследование, приостанавливает его исполнение. Таким образом, расширение процессуальной независимости дознавателя позволит ему перейти на новый уровень отношений с надзирающим прокурором.

При этом следует учитывать, что само по себе рассмотренное законодательное нововведение, по нашему мнению, не способно существенно повысить эффективность процессуальной деятельности дознания и обеспечить незамедлительную защиту прав и законных интересов лиц и организаций, потерпевших от преступлений, при сохранении уровня гарантий прав личности от незаконного и необоснованного обвинения.

Однако, если рассматривать законопроект как одно из звеньев цепи, которая ведет к кардинальному реформированию системы предварительного расследования, можно констатировать, что в этой новелле, безусловно, присутствует определенная логика.

Напомним, что идея о создании Объединенного следственного комитета впервые появилась в 2003 г. В 2007 г. были сделаны первые шаги по ее воплощению в жизнь: создано самостоятельное ведомство - Следственный комитет ${ }^{[1} 0^{]}$. Далее в 2010 г. по аналогии со ст. 163 «Производство следствия следственной группой» в УПК была введена ст. 223.2. «Производство дознания группой дознавателей» [11]. В продолжение реформы в 2013 г. законодатель ввел еще одну форму расследования - упрощенное дознание [12]. Таким образом, конечной целью реформы по созданию Объединенного следственного комитета (ОСК), в который войдут следственные органы МВД, ФСКН и Следственного комитета, является полное упразднение предварительного следствия в системе МВД и ФСКН. Единственной формой расследования останется дознание, и в этой связи в общем контексте реформы улучшение регламентации дознания, укрепление статуса дознавателя и расширение его полномочий является оправданным. Однако, учитывая сложившуюся в настоящее время внешнеполитическую ситуацию и 
DOI: $10.7256 / 1811-9018.2014 .12 .13757$

При цитировании этой статьи сноска на dоі обязательна

Судебная власть

экономические трудности, с которыми столкнулась Россия, очевидно, что завершение реформы, требующей огромного финансирования (По подсчетам авторов законопроекта, создание единого следственного комитета обойдется бюджету почти в 100 млрд рублей. Информационный сайт газеты Известия [Электронный ресурс]. URL: http://izvestia.ru/ news/573312 (дата обращения 24.10.2014)), в ближайшие годы не предвидится. Конечно, наличие проблемы отрицать нельзя, однако для ее решения принятия одного законопроекта недостаточно, требуется комплексный организационный подход. И в этой связи расширение полномочий дознавателя кажется преждевременным шагом.

\section{Библиография:}

1. Законопроект № 555400-6 «О внесении изменений в Уголовно-процессуальный кодекс Российской Федерации в части наделения дознавателя правом обжалования некоторых решений прокурора по уголовному делу, поступившему с обвинительным актом или обвинительным постановлением» от 18.06.2014 г. (в ред. 26.06.2014 г.) Офиц. сайт Государственной Думы РФ. [Электронный ресурс]. URL: http://asozd2c.duma.gov.ru/addwork/scans.nsf/ID/4BAB214FF43E183943257D0300647556/\$FILE/555400-6.PDF?OpenElement (дата обращения 19.09.2014).

2. Васильев Д. Полномочия дознавателя при возвращении уголовного дела прокурором // Законность, 2010. № 1. С. 44-45.

3. Гаврилов Д. Б. Возвращение уголовного дела для производства дополнительного расследования и устранения препятствий его рассмотрения судом: дис. ... канд. юрид. наук. М., 2008. 233 с.

4. Скударева Н. И. Современные особенности правовой регламентации дознания в органах внутренних дел: автореф. дис. ... канд. юрид. наук. М., 2006. 26 c.

5. Интервью начальника ВНИИ МВД России генерал-майора милиции С. Гирько газете Щит и Меч Объединённая редакция МВД России 24.04.2008 [Электронный ресурc]. URL: http://www.mvd.ru/struct/3985/3992/5429/ (дата обращения: 30.09 .2014 г.).

6. Баранов А. М. Законность в досудебном производстве по уголовным делам: автореф. дис. ... д-ра юрид. наук. Омск, 2006. 39 с.

7. Пояснительная записка к законопроекту № 555400-6 «О внесении изменений в Уголовно-процессуальный кодекс Российской Федерации в части наделения дознавателя правом обжалования некоторых решений прокурора по уголовному делу, поступившему с обвинительным актом или обвинительным постановлением» от 18.06.2014 г. (в ред. 26.06.2014 г.) Офиц. сайт Государственной Думы РФ. [Электронный ресурc].URL: http://asozd2c.duma.gov.ru/addwork/scans.nsf/ID/4BAB214FF43E183943257D0300647556/\$FILE/555400-6. PDF?OpenElement (дата обращения 19.09.2014).

8. Мичурина О. В. Концепция дознания в уголовном процессе Российской Федерации и проблемы ее реализации в органах внутренних дел: автореф. дис. ... д-ра юрид. наук. М., 2008. 60 с.

9. Лодкин А. Е. Совершенствование деятельности органов дознания в РФ: дис. ... канд. юрид. наук. М., 2009. 209 с.

10. Федеральный закон от 5 июня 2007 г. № 87-Ф3 «О внесении изменений в Уголовно-процессуальный кодекс Российской Федерации и Федеральный закон «О прокуратуре Российской Федерации» [Электронный ресурc]. URL: http://www.rg.ru/2007/06/08/genprokuraturadoc.html (дата обращения 24.10.2014);

11. Федеральный закон от 6 июня 2007 г. № 90-Ф3 «О внесении изменений в Уголовно-процессуальный кодекс Российской Федерации» [Электронный pecypc]. URL: http://www.rg.ru/2007/06/09/upk-izmenenia-dok.html (дата обращения 24.10.2014).

12. Федеральный закон Российской Федерации от 23 июля 2010 г. N 172-Ф3 «О внесении изменений в Уголовно-процессуальный кодекс Российской Федерации» [Электронный ресурc]. URL: http://www.rg.ru/2010/07/27/upk-dok.html (дата обращения 24.10.2014).

13. Федеральный закон от 04.03.2013 № 23-Ф3 «О внесении изменений в статьи 62 и 303 Уголовного кодекса РФ и Уголовно-процессуальный кодекс РФ» [Электронный ресурc]. URL: http://base.garant.ru/70326874/(дата обращения 24.10.2014).

14. . С. Заровнева Проблемы дифференциации форм предварительного расследования // Право и политика.-2012.-7.-С. 1219-1226.

\section{References (transliterated):}

1. Vasil'ev D. Polnomochiya doznavatelya pri vozvrashchenii ugolovnogo dela prokurorom // Zakonnost', 2010. № 1. S. 44-45.

2. Gavrilov D. B. Vozvrashchenie ugolovnogo dela dlya proizvodstva dopolnitel'nogo rassledovaniya i ustraneniya prepyatstvii ego rassmotreniya sudom: dis. ... kand. yurid. nauk. M., 2008. 233 s.

3. Skudareva N. I. Sovremennye osobennosti pravovoi reglamentatsii doznaniya v organakh vnutrennikh del: avtoref. dis. ... kand. yurid. nauk. M., 2006. $26 \mathrm{~s}$.

4. Baranov A. M. Zakonnost' v dosudebnom proizvodstve po ugolovnym delam: avtoref. dis. ... d-ra yurid. nauk. Omsk, 2006.39 s.

5. Michurina O. V. Kontseptsiya doznaniya v ugolovnom protsesse Rossiiskoi Federatsii i problemy ee realizatsii v organakh vnutrennikh del: avtoref. dis. ... d-ra yurid. nauk. M., 2008. $60 \mathrm{~s}$.

6. Lodkin A. E. Sovershenstvovanie deyatel'nosti organov doznaniya v RF: dis. ... kand. yurid. nauk. M., 2009. 209 s.

7. G. S. Zarovneva Problemy differentsiatsii form predvaritel'nogo rassledovaniya // Pravo i politika.-2012.-7.-C. 1219-1226. 